\title{
A NEW FORM OF PRESENTATION OF RENAL ACTINOMYCOSIS: RENAL TUMOR WITH RETROPERITONEAL BLEEDING.
}

\author{
Antonio Jalón Monzón', Miguel Álvarez Múgica', Miguel Ángel Seco Navedo², Jesús Maria \\ Fernández Gómez', Verónica Bulnes Vázquez³, Roberto Carlos González Álvarez', Francisco \\ Javier Martínez Gómez' y Francisco Javier Regadera Sejas'.
}

Urology Department. Hospital Universitario Central de Asturias. Oviedo. Spain.

${ }^{2}$ Anatomic Pathology Department. Hospital Universtario Central de Asturias. Oviedo. Spain.

${ }^{3}$ Radiology Department. Hospital Universitario Central de Asturias. Oviedo. Spain.

Summary.- OBJECTIVE: The aim of this case report is to add to the literature a new case of renal actinomycosis, but with a form of presentation that has never been reported: renal tumor with retroperitoneal bleeding.

METHODS/RESULTS: We present the case of a 27 year old woman, with a 5-month history of general syndrome and right flank pain. Radiological findings showed a right renal tumor with suspicious of retroperitoneal bleeding. Right radical nephrectomy was performed and the pathological examination of the specimen found actinomyces colonies. The patient received 8 weeks of Penicillin after surgery and had none sequelae.

CONCLUSIONS: Renal actinomycosis is an uncommon chronic infection caused by a gram-positive anaerobic actinomyces bacteria, usually actinomyces israelii, not

Antonio Jalón Monzón

Servicio de Urología 1

Hospital Universitario Central de Asturias

C/ Celestino Villamil s/n

33006-Oviedo. Asturias. (Spain)

ajalonm@hotmail.com

Accepted for publication: 1st January, 2006 easily diagnosed because of non-specific clinical and radiological findings. Early diagnosis of renal actinomycosis is important to avoid surgery since actinomyces respond well to high doses of Penicillin.

Keywords: Renal actinomycosis. Chronic infection. Penicillin.

Resumen.- OBJETIVO: El objetivo de este artículo es añadir que en una forma de presentación nunca antes sido publicada: tumor renal con sangrado retroperitoneal.

MÉTODOS: Presentamos el caso de una mujer de 27 años con síndrome constitucional y dolor en flanco derecho de cinco meses de evolución. Las pruebas radiológicas mostraron un tumor renal derecho con sospecha de sangrado retroperitoneal. Se realizó nefrectomía radical derecha y el estudio patológico encontró colonias de actinomices. El paciente recibió penicilina durante ocho semanas después de la cirugía y no tuvo secuelas.

CONCLUSIONES: La actinomicosis renal es una infección crónica poco frecuente producida por actinomices, generalmente actinomices israelii, una bacteria gram positiva anaerobia de difícil diagnóstico debido a los hallazgos clínicos y radiológicos inespecíficos. Es importante diagnóstico precoz de la actinomicosis renal para evitar la cirugía, puesto que el actinomices responde bien a altas dosis de penicilina.

Palabras clave: Actinomicosis renal. Infección crónica. Penicilina. 


\section{CASE REPORT}

A 27 years old woman previously in good health, presented a 5 -month history of general fatigue, a weight loss of $8-10 \mathrm{~kg}$ and right flank pain. On physical examination a palpable abdominal mass was detected. Laboratory tests showed severe anaemia (hemoglobine $6.1 \mathrm{~g} / \mathrm{dl}$ ). Abdominal ultrasonography and tomography yielded a right renal mass with retroperitoneal bleeding (Figure 1) and multiple bilateral pulmonar nodules (Figures 2). Neovascularization and chronic right renal vein thrombosis without evidence of active bleeding was demonstrated in selective angiography (Figure 3). Blood, urine and sputum cultures were negative as well as tumor markers. Right nephrectomy was performed. The right kidney was firmly adherent to adjacent tissues and dissection was very difficult. Pathological examination showed fibrous tissue with mixed acute and chronic inflammatory cells. There were also multiple microabscesses. On further microscopic evaluation a branching, filamentous, gram-positive bacteria with a "sulfur granule" appearance consistent with actinomycosis was found (Figure 4). In this patient the source and spread of actinomycosis can only be hypothesized. Since no intraabdominal etiology was identified, the origin was probably oral with thoracic and finally abdominal spread.

\section{DISCUSSION}

Actinomycosis is a chronic granulomatous infection with a worldwide distribution (1). Actinomyces

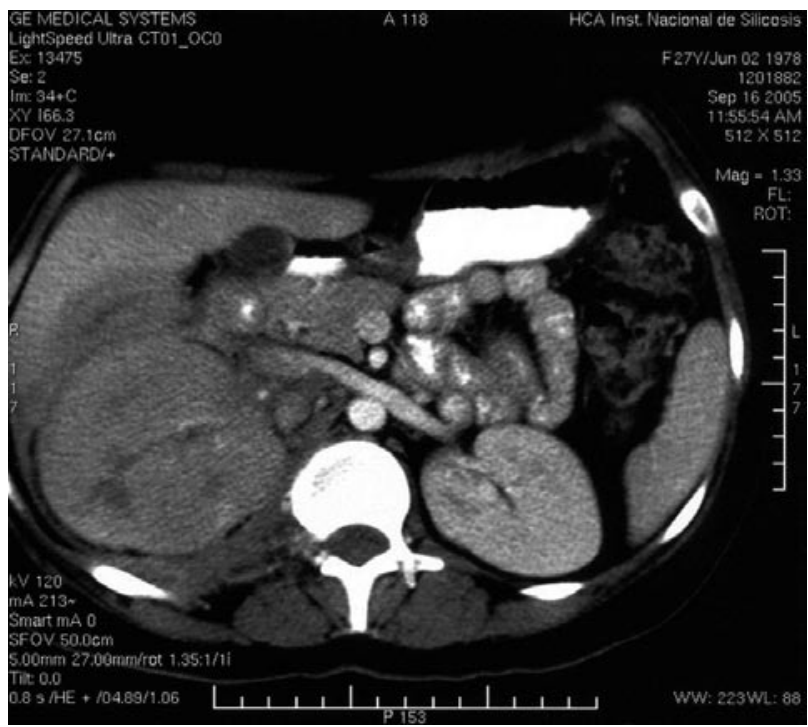

FIGURE 1. Abdominal CT. Right renal mass with retroperitoneal bleeding. israelii, a gram-positive anaerobic microorganism, is the most common pathogenic agent involved. In the human, actinomyces is a harmless saprophyte in the mouth, tonsils and gastrointestinal tract, causing disease under special circumstances, during trauma, viscous perforation or surgery $(2,3)$. Predisposing factors include diabetes mellitus, immunosupression, long term use of contraceptive intrauterine devices (pelvic disease), previous surgery (post-appendectomy abdominal actinomycosis), dental extraction, trauma and poor dental hygiene (cervico-facial disease) (4).

Genitourinary actinomycosis is a very rare entity. Clinical findings are usually non specific and may include abdominal pain, urinary frequency or repetitive cystitis. Generally, there is a long term interval between the onset of symptoms and diagnosis. The diagnosis is primarily histological identification. Cultures are often unsuccessful in determining causative factors, being positive in less than $50 \%$ of cases $(1,5)$. In the genitourinary tract, actinomyces can cause primary renal infection $(1,2,5,6)$, including a horseshoe kidney (7), reno-duodenal fistula (8) and reno-colic fistula (9). Other manifestations of actinomyces have been reported: retroperitoneal mass, ureteral stenosis, scrotal mass, prostatitis, penile pilonidal sinus and cystitis (10).

The route of infection in renal actinomycosis is still controversial. In addition to direct spread from contiguous structures such as lungs or colon, $(1,5,6)$ and aspiration of infected material, hematogeneous dissemination also occurs. By the time the kidney is involved the original lesions might have dissapeared completely. Four type of renal lesions have been

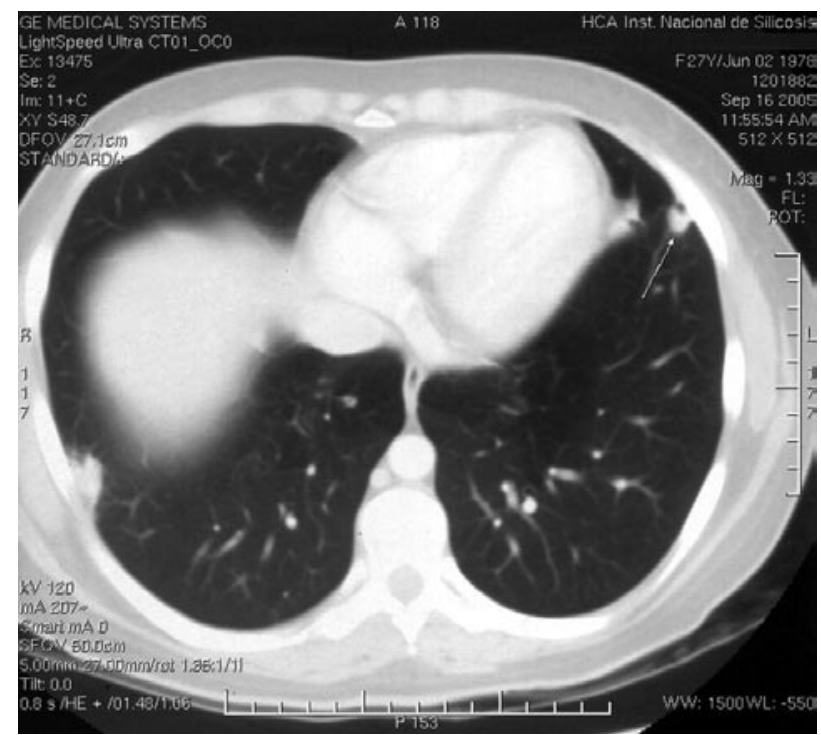

FIGURE 2. Chest CT. Multiple bilateral pulmonary nodules. 
described: chronic suppurative lesion (carbuncle), renal mass, pyelonephritis and pyonephritis $(5,6)$.

Renal actinomycosis is not easily diagnosed on the basis of clinical and radiological findings, because of its close resemblance to a variety of inflammatory processes and neplastic conditions $(3,5)$. Clinical features are not specific and depends on the duration and site of involvement. Laboratory data often suggest infection but fever is not a frequent symptom (1).

Computed Tomography (CT) is the method of choice for evaluation of characteristics and extent of the process. Its findings vary according to the stage of the disease and the region involved (1). There are two types of pattern in CT:

1. Predominantly solid masses with focal areas of low attenuation. Contrast enhancement is variable, although it is generally lower than that of muscles and solid viscera. If loculations are visible, contrast enhancement of the walls and septa may occur (3).

2. Predominantly cystic masses with thick enhancing walls (1).

Ultrasound image of the renal mass is nonspecific, but different from the typically focal appearance of renal carcinoma.

Magnetic Resonance Images (MRI) may be a useful tool for the diagnosis of renal actinomycosis. A low iso-intensity mass on $\mathrm{Tl}$ weighted MRI and a low intensity mass on T2 weighted MRI. These findings on

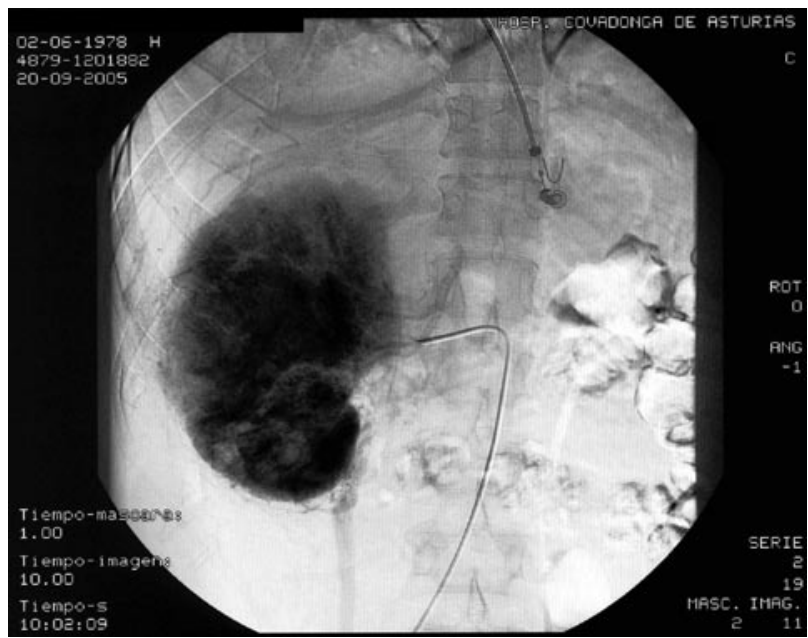

FIGURE 3. Right renal angiography. Chronic right renal vein thrombosis and neovascularization without evidence of active bleeding.
MRI can help to distinguish actinomycosis from other entities such as malignant lymphoma. Differential diagnosis include inflammatory processes (tuberculosis), abscess and neoplasms (renal cell carcinoma, lymphoma, angiomyolipoma and oncocytoma). Although most cases of actinomycosis occur between 15 and 35 years of age, there are cases described in children under 10 years of age. In these situations the differential diagnoses has to be made with Wilms' tumor, clear cell sarcoma, nephoblastomatosis, rhabdoid tumors and congenital mesoblastic nephroma $(3,10)$.

Pathological examination of the specimen shows fibroadipose tissue and a mix of acute and chronic inflammatory reaction with areas of fibrosis and granulation tissue. The presence of focal granulomatous lesions with giant cells can be noted as well as multiple irregularly shaped microabscessses with "sulfur granules", oval basaloid bodies composed

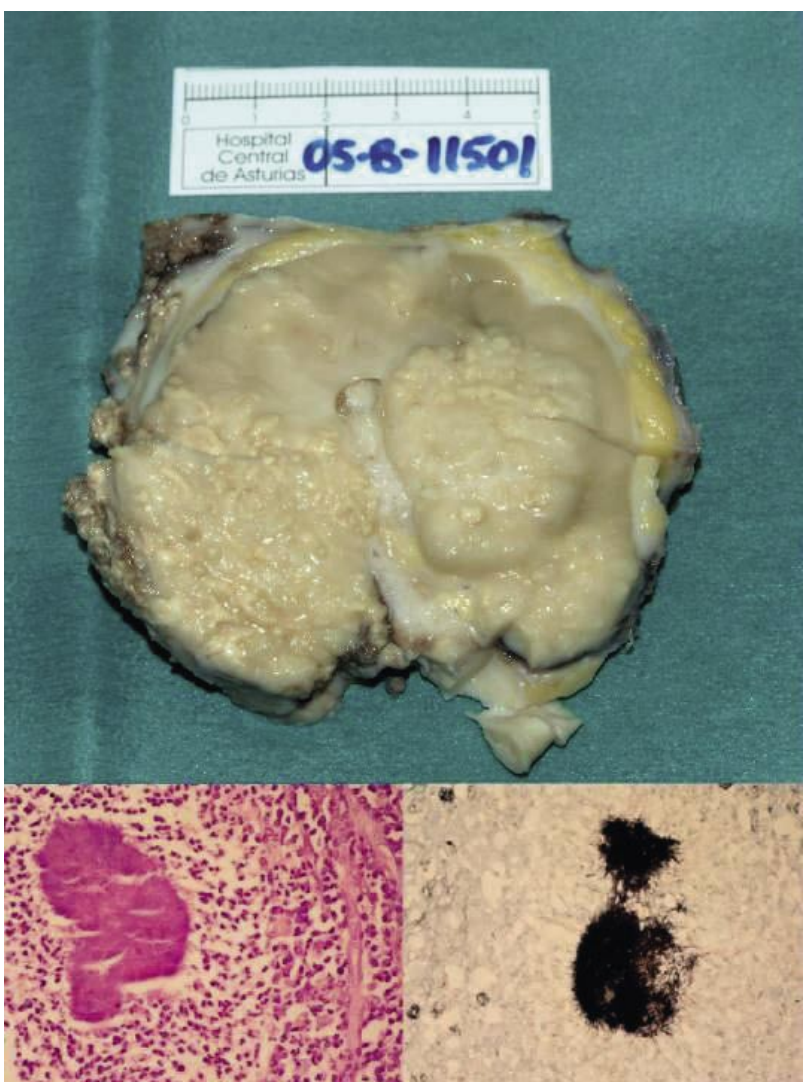

FIGURE 4. Severe right kidney desestructuration caused by the presence of a solid mass occupying more than half of the renal parenchyma. Microscopically, multiple granulomatous lesions and microabscesses were found with gram positive colonies of actinomyces, surrounded by chronic inflammation cells. A silver staining showed a well delimited aspect of the colonies. 
of filamentous organisms that stained positively with Gram's, periodic acid-Schiff and Gomori's methenamine silver stains $(1,3)$.

The prognosis of this entity is well related with the progression at the time of diagnosis. Traditionally the treatment of renal actinomycosis has been surgical extirpation of the kidney followed by prolonged antibiotic therapy. However, in early stages, solitary renal actinomycosis, may be successfully treated using prolonged antibiotic therapy ( 8 weeks- 1 year) with minimal or none sequelae $(3,6)$.

\section{REFERENCES AND RECOMENDED READING}

\section{(*of special interest, ${ }^{* *}$ of outstanding interest)}

*1. HORVÁTH, K.; PORKOLÁB, Z.; PALKÓ, A.: "Primary renal and retroperitonral Actinomycosis". Eur. Radiol., 10: 287, 2000.

**2. DHANANI, N.N.; JONES, D.M.; GROSSMAN, H.B.: "Medical management of renal Actinomycosis". J. Urol., 171: 2373, 2004.

*3. ALLEN, H.A.; SCATARIGE, J.C.; KIM, M.H.: “Actinomycosis: CT findings in six patients". AJR, 149: 1255, 1987.

4. LEACH, T.D.; SADEK, S.A.; MASON, J.C.: "An unusual abdominal mass in a renal transplant recipient". Transpl. Infect. Dis., 4: 218, 2002.

5. PATEL, B.J.; MOSKOWITZ, H.; HASHMAT, A.: "Unilateral renal Actinomycosis". Urol., 21: 172, 1983.

**6. KHALAFF, H.; SRIGLEY, J.R.; KLOTZ, L.H.: "Recognition of renal Actinomycosis: Nephrectomy can be avoided. Report of a case". Can. J. Surg., 38: 77, 1995.

*7. McGIBNEY, D.; CLARKE, P.B.: "Primary renal Actinomycosis in the presence of horseshoe kidney". Br. J. Urol., 58: 566, 1986.

*8. CVETKOV, M.C.; ELENKOV, C.; GEORGIEV, M. y cols.: "Renal Actinomycosis complicated by renoduodenal fistula and diabetes mellitus". Br. J. Urol., 75: 104, 1995.

9. YU, H.H.; YIM, C.M.; LEONG, C.H.: "Primary Actinomycosis of kidney presenting with reno-colic fistula". Br. J. Urol., 50: 140, 1978.

10. MAKAR, A.P.; MICHIELSEN, J.P.; BOECKX, G.J.; VAN MARCK, E.A.: "Primary Actinomycosis of the urinary bladder". Br. J. Urol., 70: 205, 1992. 